\title{
The Adoption Drivers of New Technology: The Case of Genetically Modified Crop Adoption by French Farmers
}

\author{
Agnès Fargue-Lelièvre ${ }^{1}$, Mourad Hannachi ${ }^{1} \&$ François-Christophe Coléno $^{1}$ \\ ${ }^{1}$ UMR SAD-APT AgroParisTech-INRA, Thiverval-Grignon, France \\ Correspondence: Mourad Hannachi, UMR SAD-APT AgroParisTech-INRA, Bat. EGER BP01, F-78850 \\ Thiverval-Grignon, France. Tel: 33-144-081-689.
}

URL: https://doi.org/10.5430/jms.v10n5p1

\begin{abstract}
This work is the first study of adoption of GM crops by French farmers. The GM crop technology case was a fertile field for the study of technology adoption but existing literature mainly focuses on studies of these issues in USA, Africa and Asia. In France, main production area of maize in Europe, the agricultural sector is very atypical compared to the agricultural sector investigated in the existing literature on the GMO adoption. By a study of the GM crop adoption in the French context and within the main production area, the south-west region of France, this study reveals 4 determinant factors that shape the choice of GM or NGM maize cropping. Some of the factors pointed by this study are in line with the existing literature on technology adoption and output uncertainty and input uncertainty (uncertainty on the expected marginal benefits and costs to sustain the new technology). Other factors identified under the atypical French agriculture sector distinctive features are particularly novel. These new factors are linked to the implementation of the UE regulation on GM/NGM coexistence in the context of small fragmented farms (need of coordination between farmers to prevent GM dispersal) and importance of the market outlets proximity to federate farmers. These novel results pinpoint that in the French context there is a need of both vertical coordination (farmers with the operators downstream the supply chain as the outlet industrial) and horizontal coordination (among farmers in neighbourhood situation) to foster the technology adoption in such industry context.
\end{abstract}

Keywords: coexistence, corn, farming system, France, GMO adoption, maize

\section{Introduction \& Theoretical Background}

The decision to adopt a new technology has been widely investigated throughout the literature. According to the technology adoption studies, since Rogers (1962), diffusion of a technology is characterized by five stages: awareness, interest, evaluation, trial, and adoption. Thus, according to this framework, adoption is the final step of the diffusion process and is part of decision making. Whereas "diffusion" is generally linked to collective decision drivers (Biemans, 2018), the adoption (even if it is linked with the collective drivers and other diffusion stages to collective) appears to be explicitly linked to actions taken by individual agents (Berry and Berry, 2018). Thus, the "adoption" calls for going beyond the collective and/or territorial drivers and to focus and take into account to the act of choice by individuals (Makkonen et al., 2016; Damanpour et al., 2018).

In this article, we propose to define adoption as the decision on the part of the individual to adopt innovation under the influence of perception on the new technology and a host of exogenously determined variables (for example in our case of maize farmers: farm size, land tenure, farm structure well as individual differences across farmers business).Historically, the GM crop technology case was a fertile field for the study of the technology adoption. According to the literature on the adoption, from a general point of view, a decision maker will invest in a new technology if this helps reduce the causes of uncertainty he has to face and when the expected marginal benefits are larger than the costs he has to sustain. By carrying the promise of an increase of the yield and a reduction of pesticides, the GM crops exemplify a new form of farming compared to the technology adoption studied in the literature in the late 1970s/early 1980s (Dillon, 1971; Anderson, Dillon \& Hardaker, 1977). In those years, most studies focused on the benefits of introducing new technology in farm production (ex. hybrid maize technology), where the main question was whether the higher pesticide and fertilizer requirements of the new crop was sufficiently offset by higher yields. 
Since these seminal researches, many scholars have attempted to formalize the decision-making process of farmers who face to such uncertainty and how the farmers face risk (i.e. outcomes are not guaranteed). Despite the large number of studies on risk and uncertainty in the adoption of new technologies, there is a phenomenon commonly observed on new technology adoption: farmers' risk preferences lead risk-averse individuals to postpone the adoption decision, and thus this lead to a Sigmoidadoption curve.

On the one hand, the adoption of a new technology can be conceived as resulting from a fine balancing act between its profitability and the farmer's attitude towards the risk associated with it. An impressive set of empirical evidence among the early literature of new technology adoption, has shown that farmers in developing countries are risk averse and tend therefore to delay the decision to adopt a new technology (Moscardi \& de Janvry, 1977; Dillon \& Scandizzo, 1978; Antle, 1987; Binswanger, 1980, Long et al., 2016). According to these studies, even a small uncertainty linked to the growth in pesticide costs, as well as the greater prices of the seeds, could engender a reduction of adoption and the postponement by risk-averse farmers of the decision to adopt a new crop variety.

Farm size and land endowment are two other important diversifying features affecting the decision to adopt a new technology. In the empirical studies, a positive relation between adoption and farm size is often found when food security is not a binding constraint, or when there are fixed transaction and information acquisition costs associated with the new technologies, therefore preventing smaller farms to engage in innovation (Feder \& O'Mara, 1981; Feder, Just \& Zilberman, 1985, Warren et al., 2016). Researches, such as Cohen and Klepper (1996), have encompassed the Sigmoid curve of the adoption in agriculture. Nevertheless, other researches have revealed a negative relationship between farm size and technology adoption, mostly due to farmers' risk aversion and their inclination to follow a technological ladder in adoption (Wubeneh and Sanders, 2006).

All these cases studies and the aggregated literature divulges that the degree of adoption and dissemination of these modern technologies varied across and within countries, with differences due to size of the farm, risk attitudes and geographical locations (James, 2008, Barnes et al., 2019).

\subsection{The GM Crop Case}

The existing literature mainly focuses on studies of these issues on the GM crop adoption in the USA, Africa and Asia cases. No studies were done in the context of France which contains the main production area of maize in Europe (the south-west region). In France, the agricultural sector is very atypical compared to the agricultural sector investigated in the existing literature on the GMO adoption. The French agricultural sector is characterized by very fragmented farm field patterns and the French supply chain is less integrated than other supply chains or agricultural sectors in others countries. In France, the supply chain involves a diversity of actors operating at different levels (Ménard \& Klein 2004). This last fact makes it more important to investigate the adoption of technology in this context at the farm level as a focal unit.

In this article we focus on this gap by the study of the adoption of the GM crop by French Farmers. More precisely our aim is to identify the factors of adoption of the GM crop technology by farmers under two particular and rare features offered by the French agricultural sector: the very fragmented farm field pattern and the less integrated supply chain.

The article is organized as follows: first, we will present the context of GM technology in the UE and France, and then we will present our survey methodology, the data and area investigated. We then summarize our empirical and analytical results and discuss them towards the literature. The last section provides conclusions and perspective implications.

\subsection{Scope of the Study: The Case of GM Crop Technology in France}

In the European Union, the principles of the coexistence between GM (Genetically Modified) and non GM (NGM) crops have been defined by several directives and recommendations that, at the agricultural production level, aim at limiting the fortuitous presence of GMO in conventional harvests. In particular, the farmer introducing a GM crop has to bear the responsibility of using means to limit the mixing between GM and non GM crops (European Commission, 2003a). Under European regulations a product containing more than $0,9 \%$ of one of its ingredients coming from GM material is labelled as GM (European Commission, 2003b).

Bt maize (resistant to corn borer) is the only GM crop commercially grown in the EU and has already been cropped in France, especially in 2007. It was therefore chosen to focus the current study on maize.

In France, only two years of GM maize cropping were available for study since a moratorium was declared in 2008 and has not been lifted since. In France, 492ha of Bt maize was cropped in 2005, 5000ha in 2006 and 22 000ha in 
2007 out of a mean maize area of more than 3 million ha per year. Therefore the farmers studied were those trying GM maize mainly for the first or second year and not cropping it as a usual variety. The originality of the current within the French studies is that it was based on real cases of GM maize cropping and not on discussion of potential adoption (Duquesne, 2005).

The farmers' decision for adoption of GM maize in France has been conceptualised with a simple economical model based on the maximisation of gain expectancy for the farmer (Coléno \& Angevin, 2012). However, this model only takes into account an economic reasoning whereas adoption of GM maize cannot be explained by a purely theoretical economic reasoning and calls for field investigation to explore the practices and behaviours in the field. In order to deepen the issue of GM crop adoption by farmers in the French context we studied the GM maize adoption in real case farms. Our aim was to identify the factors determining its adoption and the cropping systems associated both with GM and NGM maize in the context of the French farms. The context of French farms is an atypical context towards the case studies in the existing literature because in France the farms are smaller and have a very fragmented farm on a geographical dimension. The objective of the current study was to identify simple indicators, even indirect ones, of GM maize adoption in order to improve the literature on the GM crop technology adoption.

GM crop adoption was studied in the South-West of France, the main maize grain production area in France where corn-borer is present with frequently two cycles per year. Our study was done at the farm level in 2006 and 2007.

To ensure the identification of determining factors, several systems were studied, maximizing their diversity and thus ensuring the identification of a maximum constraints and/or interests of Bt maize cropping that could explain its adoption or not by the farmer.

\section{Methods}

\subsection{Region Surveyed}

The Midi-Pyrénées region (South of France) was chosen because of the importance of maize crop in the farmer's income in this region and the high corn-borer pressure, which insured that GM maize would have a technical interest for farmers.

The goal was to survey a wide diversity of farms, which had been confronted to GM-NGM maize coexistence in 2006 and/or 2007, and which were producing GM, NGM or both, maize. An area where mixed farming production systems could be found was thus chosen, using the French Ministry of Agriculture's statistical data (Agreste Midi-Pyrénées, 2009) and where GM maize represented a high proportion of cropped maize, using governmental data (République Française, 2008).

Two departments represented nearly three quarters of the GM maize cropped in Midi-Pyrénées in 2007: Haute-Garonne and Tarn-et-Garonne. In the Verdun-sur-Garonne County especially, maize was the main crop and GM maize had been cropped on more than half the total maize area in 2007. An area in and around Verdun-sur-Garonne was chosen over both Haute-Garonne and Tarn-et-Garonne departments.

The area surveyed covered 6 counties, where GM maize was cropped on a quarter to more than half the total maize crop. These counties also contained a high diversity of production system (data source: General Agricultural Census/RGA 2000). However, a little over half of the 23 farms surveyed were situated in the Verdun-sur-Garonne County.

\subsection{Survey and Analysis Method}

The sample was build using the «snowball» method, first finding farmers via the phone directory and then filling out with contacts given by the farmers themselves. These farms were thus first chosen in a general database with no relation to the agricultural sector, avoiding the usual bias induced by the use of a database given by grain merchants or technical advisors.

Using semi-directive interviews, 23 farms were surveyed using the method described in Miles and Hubermen (1994). An interview guideline was used but let the farmer speak freely and choose the order in which he talked about the different points.

The questions were about the farm and its management: farm resources (Usable Arable Area -UAA-, soils, distances between farm and plots, labour, equipment including stocking sheds and type of irrigation...), productions on the farm (crops, livestock, production's importance in the final income and its destination), maize crop management (maize yield, types of maize cropped, cropping system, crop localization, crop rotations, pests presence and management, coexistence means used, labour organization), commercial and advising relations as well as the 
farmer's view on the impacts (advantages and constraints) of GM maize on his system (technical, organizational and commercial) and his perception of the evolution of maize cropping in the region.

These interviews were then synthesized and analysed to identify the relations between the data concerning the farm, the farm management and the presence of GM maize or not on the farm as well as the coexistence means used.

\section{Results}

\subsection{Global Sample Structure}

The 23 farms surveyed represented a very diverse sample of maize producers: 15 combinations of production were found from the cereals and oleo-proteinaceous crop producer (5 farms) to the cereal/duck/seeds/fruit producer (1 farm). This fulfilled our goal to reflect the diversity of maize producers in the region. Livestock farming was present in 6 farms (cattle, chicken, and duck), seeds in 7 farms, orchards in 8 farms and vegetables in 3 farms. Two organic farms were also surveyed.

In 7 of the 23 farms, the farmer had another activity (primary or secondary) in relation with agriculture (6 farms) or not (both farmers in this farm).

Farm size varied from 33ha to 280ha (Table 1) with 1 to 4 individuals working on the farm and maize grown on less than a tenth to more than three quarters of the UAA (Usable Arable Area) (Figure 1).

Table 1. Maize cropped area in the sampled farms

\begin{tabular}{llll}
\hline Sample analysis & Minimum & Median & Maximum \\
\hline UAA (ha) & 33 & 120 & 280 \\
\hline \% Maize in the UAA & 7,6 & 37 & 80 \\
\hline \%GM maize in total maize (For all farms) & 0 & 22 & 100 \\
\hline For farms that cropped GM maize & 5 & 55 & 100 \\
\hline
\end{tabular}

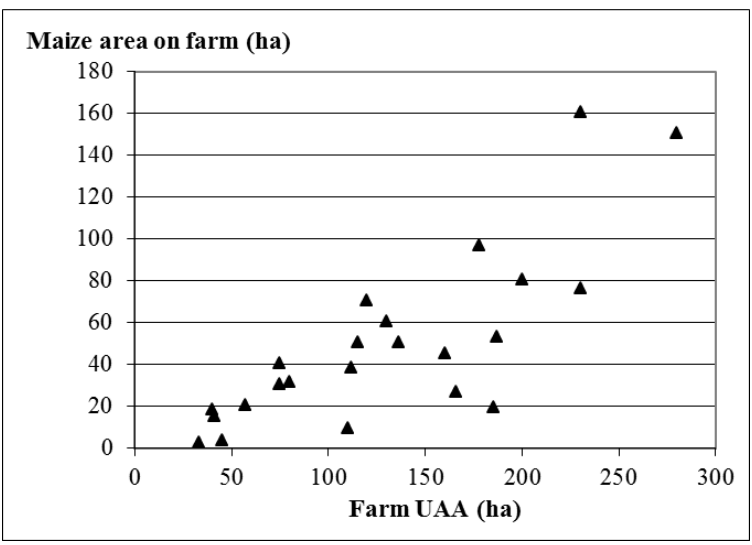

Figure 1. Cropped maize area and total farm acreage by farm

Maize was the main income source for 13 farms.

The majority of the farms had a highly aggregated field pattern with the most distant plot less than $5 \mathrm{~km}$ away in 12 of the 20 farms where this data was available.

The minimum mean maize yield in our sample was $40 \mathrm{q} / \mathrm{ha}$ (seed maize production), the maximum was $150 \mathrm{q} / \mathrm{ha}$ and the median $115 \mathrm{q} / \mathrm{ha}$, which was a little higher than the regional mean maize yield of this year $(100 \mathrm{q} / \mathrm{ha})$.

\subsection{Maize Management}

The sowing date was more or less stable between farms: it was highly dependent on the rain in April and May, which was frequent. Sowing date varied between the beginning of April and the end of May depending on the year and the rain pattern. 
Nitrogen doses varied considerably between farms from 80 to $300 \mathrm{~kg} \mathrm{~N} / \mathrm{ha}$ but no clear relation could be found between nitrogen input and maize yield.

Except in organic farms, maize was treated with one systematic herbicide before maize germination. This treatment was added to when necessary or systematically with another herbicide depending on the farm.

Corn-borer and sesamia were perceived as a risk for maize yield in 12 of the 19 farms where this data was available, but only 8 of those 12 farmers treated their maize crop with a pesticide. The helicopter treatment was given up from 2006 by those who did it.

The numbers of varieties used each year in farms were compared with total maize area and return time of maize on a given plot (Figure 2). Varietal choice did not seem linked to either maize area or maize return time on a plot. Thus farmers did not use varietal choice either as a mean of managing pest risk.

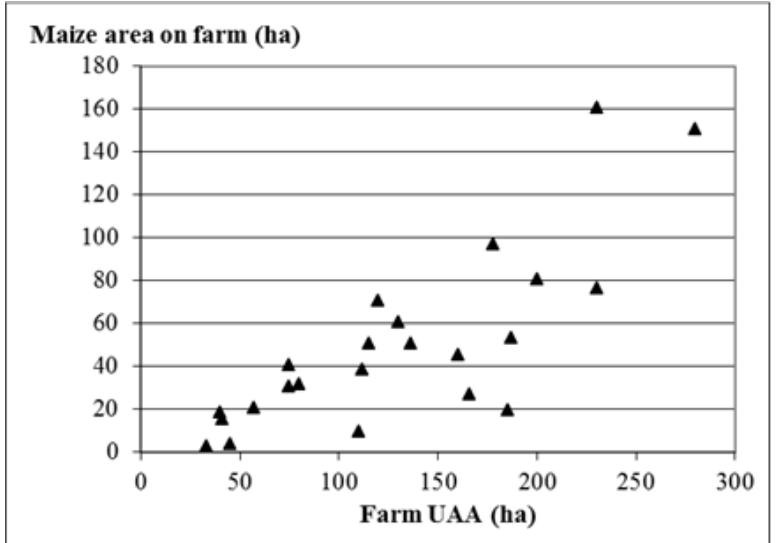

Figure 2. Relation between number of cultivars and return time for maize by farm

All but one kind of maize were irrigated but several kinds of sprinklers and driplines were found, sometimes on the same farm. Water input usually began from the ten leaves stage with an input of $30 \mathrm{~mm}$ per round for the sprinklers and a total of 5 to 8 rounds of irrigation during maize cropping. The usual input of water per round for the dripline was $16 \mathrm{~mm}$. However, there were some difficulties in obtaining homogeneous data on this subject.

Twelve farmers identified localization constraints on the maize. In 6 cases, these constraints were due to the impossibility or difficulty of irrigating some plots.

Maize harvest was mainly done by private firms (14 farms). In 8 farms only, the farmer harvested his maize himself (in one case with the help of neighbours) and in the only case of maize seed production, the seed company harvested the seed itself.

Maize monoculture was also the main crop rotation in the sample surveyed (14 farms) but some farmers waited up to 6 years before cropping maize again on a given plot.

In all cases surveyed where GM maize was cropped in 2006 and/or 2007, GM maize was managed in the same way as the NGM maize, except when the corn-borer pesticide was dispensed. It was then stopped on the GM maize.

\subsection{Means Used to Limit GMO/Non GMO Mixture}

In 2007, 14 farms cropped GM maize while one farm had cropped GM maize in 2006 but not in 2007. Overall, for these 15 farms, GM maize covered a twentieth to the whole maize area.

In 7 farms GM maize covered more than three quarters of the maize area, which was the maximum proportion recommended in the booklet on good practices given with each bag of seeds (AGPM, 2006). In the case of the 3 farms where all the maize cropped was declared as GM maize, the plots included in fact a buffer of NGM maize on 18-24 rows.

In the other 22 cases surveyed, the farmers grew maize plots in areas where both GM and NGM maize coexisted. 
In 15 of these cases, buffer zones of NGM maize were put in place around the GM maize. In the case of some of the NGM maize producers, information about the presence or not of buffer zone around the GM maize of their neighbours could not be obtained, so that the number of cases of buffer zones may well be higher than that.

Five farms isolated their maize crop from their neighbours': two farmers isolated their GM maize to keep it from pollinating NGM maize, two farmers isolated their organic maize to keep it from being pollinated by GM maize and one farmer isolated his maize seed production from all maize.

In 6 cases, farmers coordinated themselves to respect a minimum distance or a minimum buffer width between GM and NGM maize (in one out of two cases of organic maize production, in two cases of maize seed production, in one case of duck feed production and in one case of maize production for labelled cattle).

In one single case, the farmer had no near neighbours cropping maize and so did not put in place any means to limit pollen dispersal from the GM maize.

In two cases, the farmer producing GM maize did not put in place any coexistence means. In one case, there was no neighbouring NGM maize. In the other, the neighbouring NGM maize was his own and was pop-corn maize, which cannot be pollinated by grain maize.

Other coexistence means were used: in two farms, NGM maize was harvested first so as not to mix harvested grain; in one farm, NGM buffer zones were sown first so that they would be more developed than GM maize; and in one farm GM maize was sown first.

The main coexistence mean used by farmers was thus the buffer zone of NGM maize. These buffer zones were usually 24 rows wide (in 12 cases out of 15) but ranged from 18 to 24 rows. Information and coordination with the neighbours was used mainly in the case of neighbours producing specialty maize.

\subsection{General Synthesis}

One of the findings of this sample analysis was that NGM maize was found in specialty crops (organic maize, seed maize and duck feed maize). These farmers were contracted to use and produce only NGM maize due to production specifications (either written or not). Corn-borer pressure also seemed to increase adoption of GM maize: in the 12 cases of perceived corn-borer presence, 8 farmers had decided to crop GM maize; whereas in the 9 cases of perceived corn-borer absence, only 5 farmers out of 9 had decided to crop GM maize.

Crop rotation including maize (Table 2) and mean maize yield may also have an effect on GM maize adoption. Farmers with a high perceived presence of corn-borer or with a high corn-borer risk due to crop rotation used GM maize more often to limit this risk.

Table 2. GM maize adoption and crop rotation; other crop can be wheat, triticale, soybean or sunflower

\begin{tabular}{|c|c|c|c|c|}
\hline $\begin{array}{l}\text { Crop rotation with } \\
\text { maize on the farm }\end{array}$ & Monoculture & $\begin{array}{l}\text { Maize } 5 \text { years } \\
\text { /cereal }\end{array}$ & $\begin{array}{l}\text { Intermediate }(3 \text { years } \\
\text { maize/3 years } \\
\text { maize/other) }\end{array}$ & $\begin{array}{lrr}\text { Long } & \text { rotation } & (>4 \\
\text { years } & \text { between } & 2 \\
\text { maize }) & & \end{array}$ \\
\hline GMO presence & 9 farms & 2 farms & 2 farms & 1 farm \\
\hline GMO absence & 1 farm & 1 farm & 2 farms & 4 farms \\
\hline
\end{tabular}

There was no relation between farm size and GM maize presence or proportion. Mean maize yield was also unrelated to farm size.

However, our results show that only farmers with a high mean maize yield ( $>100 \mathrm{q} / \mathrm{ha}$, which was the mean yield of the region in 2007) used GM maize in our sample (15 farms). The 5 farmers with a yield lower than $100 \mathrm{q} / \mathrm{ha}$ did not use GM maize. Out of the two farmers with a yield higher than 100q/ha and no GM maize, one produced a specialty crop (duck-feed) and another was opposed to GMOs. The other farmers usually combined their high mean yield with a maize monoculture and a high nitrogen input. The only leeway left to increase their yield was to limit the hidden losses due to corn-borer. They were thus more likely to adopt GM maize. These results can be compared to that found on Bt cotton in Africa by Hofs, Hau, Marais and Fok (2006). In their study, Hofs et al. (2006) found out that using GM crop could be an important component in cropping intensification strategies but that in farms with low or variable yields it did not always bring improvements. In our study, only farmers with an intensification strategy tried GM crops. Another point in this argument is that the 5 farms with a low maize yield and no GMO were also the 5 
farms who had less than a fifth of their UAA in maize whereas the other farms had at least a quarter of their UAA in maize. This points to farms with more diverse crops and/or pastures. The 2 farms with yield higher than 100q/ha (regional mean yield in 2007) and no GM maize also had 4 and 6 crops different from maize on their farm.

During this survey, 3 kinds of advantages of GM maize over NGM maize were given by farmers:

- $\quad$ yield increase

- $\quad$ better sanitary state of the harvest

- $\quad$ more flexible work organization.

Three kinds of reason given by farmers for not cropping (again) GM maize could be identified:

- technico-economical reasons (no yield increase observed combined with a high seed cost or existence of other levers to increase yield)

- $\quad$ strategical reasons (specialty crops)

- $\quad$ ideological reasons (given alone in only one case in our survey)

In farms where the NGM maize behaved as well or better than the GM maize, farmers did not want to crop GM maize again. However, in farms where GM maize behaved better than NGM maize (better yield or better sanitary state of the crop), GM maize would be cropped again if authorized.

In 2006 corn-borer (and sesamia) presence was high and GM maize cropped this year may have had a better yield (only one farmer, out of the 7 who tried it that year, did not see a yield increase). However, in 2007, corn-borer presence was much lower and the farmers who cropped GM maize in 2007 only did not see as great a yield increase (only 3 farmers, out of 9 who tried it that year, observed a yield increase).

The consequences of testing GM maize in 2006 or 2007 seemed high on future GM adoption: 5 out of 9 farmers testing GM maize in 2007 would crop GM maize again if authorized whereas 6 out of 7 farmers testing GM maize in 2006 would crop GM maize again if authorized.

Thus, pest pressure the first year of testing seemed to be a determining factor of GM maize adoption as it impacted on the benefits the farmer saw for GM maize cropping. However, even though farmers having cropped GM maize both in 2006 and 2007 may not have seen a yield increase in 2007, they still declared themselves ready to crop GM maize again, surely as a security measure for years with a high corn-borer (or sesamia) presence.

\section{Discussion}

Our study was on a small sample and our results are thus limited in terms of possibilities of extrapolating these results to another region. However the diversity of our sample ensures that varied behaviours were encountered and thus enabled the identification of a diversity of rationales in the adoption of GM maize.

Since GM maize was cropped at a large scale in France, i.e. only in 2006 and 2007, only early adopters were encountered. As such our results, as underlined by Finger, Hartmann and Feiknecht (2009) in Argentina and Hategekimana (2002) in Canada, cannot reflect the determining factors of GM adoption long term but rather the factors determining first adoption of GM maize. However, our questionary included questions to farmers about a future cropping of GM maize if it was authorized as such, which enables us to give an insight as to a more long term possible adoption.

There was no farm size effect on GM adoption in our sample. These results are in keeping with those of Alexander and Van Mellor (2005) and Hategekimana (2002) in Canada and contrast with the previous works (Feder \& O'Mara, 1981; Feder et al., 1985) that underlined that farm size is another important driver affecting the decision to adopt a new technology. These last studies reveal a positive relation between adoption and farm size where the small farms are relatively less engaged to adopt. This contrast between this literature and our results is certainly due to the fact that in our context all the farms in the French south west region are small compared to the studies of Feder and O’Mara (1981) and Feder et al. (1985).

Other studies showed the importance of alleviated workload and more flexibility carried by the GM crop for the adoption of this technology (Fernandez-Cornejo \& Caswell, 2006). These factors were also cited by the farmers surveyed as positive impacts of GM adoption in our study.

In our sample however a new category of farmer was encountered: farmers producing maize as animal feed are not always free to choose GM maize as some production specifications (either written or not) do not allow it as seen here for 3 farmers. The breeding outlet is not always possible for GM maize in France. This may be especially true with 
the new labelling on GM and non GM products (JORF, 2012). The outlet given by farmers for their GM maize grain was either as feed in their own farm or as an export to Spain. This result may be very regional since maize production in other French region may not have this export outlet available if GM maize were again authorized. Indeed the outlet and the market proximity appear to be important drivers for the choice of adopting the new technology of GM crop.

During the survey, organic farmers cited the difficult constraints on their maize production in 2007 and both plan on stopping maize cropping in the case of GM maize return in the region. The difference with other French regions or countries (Devos et al., 2008) is the size and imbrications of organic and non organic fields in this region which puts organic maize plots in contact or proximity with conventional maize plots.

In Duquesnes (2005), the coexistence means mainly cited in the North-East of France were a shift of sowing date for GM crops, which would bring a shift in flowering date about. In the South of France however, this did not seem possible to farmers. The sowing time window seems large with a beginning of sowing at the end of March and an end of sowing at the beginning of May. However, this range covers in fact 2 or 3 smaller sowing windows near the beginning of April and the beginning of May, due to regional pluviometry and farmers tend to sow at the same time. The coexistence means must thus be adapted to a regional scale and constraints as has been suggested by Devos et al. (2008) and Sanvido et al. (2008) and the coexistence means, which farmers have put in place have been chosen to take into account these regional constraints and thus are more means of a spatial isolation than a temporal one, that was envisioned in the North-East of France (Duquesnes, 2005).

\section{Conclusion}

Several preceding studies were done on the study of technology adoption on the GM crop case but they focused mainly on adoption in the USA, Africa and Asia. Our work focused on the adoption of GM crops by French farmers in a specific context inasmuch as its agricultural sector is very atypical compared to those investigated in the preceding studies with a less integrated supply chain and smaller fields. What is more, France is the main production area of maize for Europe, especially its south-west region.

By a study of the GM crop adoption in French context and within the main production area of maize in Europe, the south-west region of France, this study reveals 4 determinant factors that shape the choice of GM or NGM maize cropping:

- The presence or not of specialty productions related to maize on the farm,

- The presence or not of other potential technical improvement of the maize yield within the farmer's strategy,

- The perception of corn borer as a risk or not, and the return time of maize on a plot.

- Our survey also showed that farmers managed GM and NGM maize in the same way except for GM's specificities: no need for insecticides but coexistence means to limit pollen dispersal to NGM maize.

The three last factors pointed by this study are in line with the existing literature on technology adoption. Technology adoption studies show that a decision maker will invest in a new technology if this helps reduce the causes of uncertainty he has to face and when the expected marginal benefits are larger than the costs he has to sustain. The new GM crops technology help farmers to handle two main sources of uncertainty: output uncertainty and input uncertainty (expected increase of the yield and decrease of the amount of pesticides used).

But our study reveals that in the case of small and fragmented farms field patterns and within the French and UE regulation on GM/NGM coexistence, the GM adoption gives rise to uncertainties on the dispersal of GM pollen and the risk of cross pollination. This point makes a need of coordination between farmers and/or a cost of isolation of crops (Note 1) appear that can shape the choice of the adoption or the postponement of GM crop in this context. This point is a novelty towards the literature on the GM crop adoption.

Besides this novelty we expected to find some novel factors on GM crop technology adoption with the study of the French agricultural sectors. There are two particularity of the French agricultural sector that we expected as important: the very fragmented farm field pattern and the less integrated supply chain

On the fragmented farm field pattern, we find that there is no farm size effect on GM adoption in our sample. But in contrast to the existing literature on this point in our study there is no large size farm in the French context.

On the less integrated agricultural supply chain in France, we underline that in France the supply chain involves a diversity of actors operating at different levels (Ménard and Klein 2004). This last fact gives rise to a large number of small farmers not integrated in vertical organizations. The number and size of farmers engenders atomicity that 
complicates the management of the dispersal of GM pollen and a strong atomicity of farmer towards the market. This last point optimizes the first factors we identified (i.e. the presence or not of specialty productions related to maize on the farm). This is to say that specific outlet market is determinant in this context on the choice of GM adoption. In the case of the absence of specific outlet in proximity that drives farmers to converge, the farmers need to coordinate themselves, which is difficult because of their large numbers (Olson, 1965) and the transaction cost (Williamson, 1981) of the coordination between themselves and with the outlet market.

This first factor and the discussion of the three other factors we identified pinpoint that in the French context there is a need of both vertical coordination (farmers with the operators downstream the supply chain as the outlet industrial) and horizontal coordination (among farmers in neighbourhood situation) to foster the technology adoption in this industry context.

\section{Limits and Perspectives}

GMO are the subject of social controversy in France. Therefore, it was difficult to reach a large sample of farmers for our study. Numerous contacted farmers declined the survey because of this controversy. Thus our research rests on a qualitative methodology which is more suitable for small sample survey research. But the methodology used enables "grounded understandings" of the technology adoption even if these understandings remain nascent premises. The qualitative approach used in this research limits the generalizability of the empirical results to other cultural contexts and to other industries.

Further researches could consider other industries or other countries in order to test these findings. It would be particularly interesting to investigate if these findings work in other industries and contexts similar to the French agricultural industry.

In France the GMO innovation was prohibited at the end of the study and our research is based on the farmers' behaviors toward the GMO innovation during only two years. A fruitful method to test and develop our understanding is to investigate within the atypical French agriculture industry, the adoption of another innovation, less controversial. Such research can overpass the sample limitation that we had. Despites theses limits, as perspectives on the issue of GMO innovation in France, these results will be used to build a multicriteria model of GM and NGM maize plot allocation in small regions. Such a model would take into account agronomical, economic and legislative criteria in order to test the effect of farmer and vertical and horizontal coordination strategies on the feasibility of coexistence via simulation of pollen dissemination at the landscape level. This model will then enable us to test in silico how the farmers react to several governance and coordination scenarios at region level and its impact on fortuitous GM presence in harvests. This will enables us to overpass in silico the difficulties we confronted in surveying farmers and we hope that the findings presented in this paper will be developed and more generalizable.

\section{Acknowledgements}

The authors would like to thank C. Auguste and all farmers for their help. This work was supported by the Agence Nationale pour la Recherche of the Ministère de l'Agriculture et de la Pêche under Grant ANR-07-POGM-PS02

\section{References}

AGPM. (2006). Guide des bonnes pratiques pour la culture du maïs Bt. AGPM.

Midi-Pyrénées, A. (2009). L'agriculture, l'agro-alimentaire et la forêt. Mémento édition 2009. Direction régionale de l'alimentation, de l'agriculture et de la forêt. Paris.

Alexander, C. E., \& Van Mellor, T. (2005). Determinants of corn rootworm resistant corn adoption in Indiana. AgBioForum, 8, 197-204.

Anderson, J., Dillon, J. L., \& Hardaker, B. (1977). Agricultural decision analysis. Ames, IA: Iowa State University Press.

Antle, J. M. (1987). Econometric estimation of producers' risk attributes. American Journal of Agricultural Economics, 69(3), 509-522. https://doi.org/10.2307/1241687

Barnes, A. P., Soto, I., Eory, V., Beck, B., Balafoutis, A., Sánchez, B., ... Gómez-Barbero, M. (2019). Exploring the adoption of precision agricultural technologies: a cross regional study of EU farmers. Land Use Policy, 80, 163-174. https://doi.org/10.1016/j.landusepol.2018.10.004

Berry, F. S., \& Berry, W. D. (2018). Innovation and Diusion Models in Policy Research. In Theories of the policy process (pp. 263-308). Routledge. https://doi.org/10.4324/9780429494284-8

Biemans, W. (2018). Managing innovation within networks. Routledge. https://doi.org/10.4324/9780203701409 
Binswanger, H. P. (1980). Attitudes towards risk: Experimental measurement in rural India. American Journal of Agricultural Economics, 62, 395-407. https://doi.org/10.2307/1240194

Byrne P. F., \& Fromherz S. (2003). Can GM and non-GM crops coexist? Setting a precedent in Boulder County, Colorado, USA. Food, Agriculture \& Environment, 1(2), 258-261.

Cohen, W. M., \& Klepper, S. (1996). Firm size and the nature of innovation within industries: The case of process and product R\&D. The Review of Economics and Statistics, 78(2), 232-243. https://doi.org/10.2307/2109925

Coléno, F.-C., \& Angevin, F. (2012). Evaluation of collection strategies for landscape and product flow management. In Y. Bertheau (Ed.), Genetically modified and non-genetically modified food supply chains. Coexistence and traceability (p. 686). Wiley-Blackwell. https://doi.org/10.1002/9781118373781.ch9

Coléno, F.-C., Angevin, F., \& Lecroart, B. (2009). A model to evaluate the consequences of GM and non-GM segregation scenarios on GM crop placement in the landscape and cross-pollination risk management. Agricultural Systems, 101, 49-56. https://doi.org/10.1016/j.agsy.2009.03.002

Damanpour, F., Sanchez-Henriquez, F., \& Chiu, H. H. (2018). Internal and external sources and the adoption of innovations in organizations. British Journal of Management, 29(4), 712-730. https://doi.org/10.1111/1467-8551.12296

Devos, Y., Thas, O., Cougnon, M., De Clercq, E. M., Cordemans, K., \& Reheul D. (2008). Feasibility of isolation perimeters for genetically modified maize. Agronomy for Sustainable Development, 28, $195-206$. https://doi.org/10.1051/agro:2007039

Dillon, J. L. (1971). An expository review of Bernoullian decision theory. Review of Marketing and Agricultural Economics, 39(1), 3-80.

Dillon, J. L., \& Scandizzo, P. L. (1978). Risk preferences of subsistence farmers in northeast Brazil. American Journal of Agricultural Economics, 60(3), 425-435. https://doi.org/10.2307/1239939

Duquesne, S. (2005). Coexistence entre maïs OGM et non-OGM: quelles marges de manœuvre dans les exploitations Haut-rhinoises? Comparaison avec un exemple espagnol. Mémoire de fin d'études. ESA d'Angers.

European Commission. (2003a). Regulation (EC) No 1946/2003 of the European Parliament and of the Council of 15 July 03 concerning the transboundary movement of genetically modified organisms. Official Journal of the European Union, L287, 1-10.

European Commission. (2003b). Regulation (EC) No 1830/2003 of the European Parliament and of the Council of 22 September 03 concerning the traceability and labelling of genetically modified organisms and the traceability of food and feed products produced from genetically modified organisms and amending Directive 2001/18/EC. Official Journal of the European Union, L268(46), 24-28.

Feder, G., \& O’Mara, G. (1981). Farm size and the diffusion of green revolution technology. Economic Development and Cultural Change, 30, 59-76. https://doi.org/10.1086/452539

Feder, G., Just, R. E., \& Zilberman, D. (1985). Adoption of agricultural innovations in developing countries: A survey. Economic Development and Cultural Change, 33, 255-98. https://doi.org/10.1086/451461

Fernandez-Cornejo, J., \& Caswell, M. (2006). The first decade of genetically engineered crops in the United States. USDA Economic Information Bulletin, 11.

Finger, R., Hartmann, M., \& Feiknecht, M. (2009). Adoption patterns of herbicide-tolerant soybeans in Argentina. AgBioForum, 12, 404-411.

Hategekimana, B. (2002). Genetically modified grain corn and soybeans in Quebec and Ontario in 2000 and 2001. Statistics Canada Agriculture Division, Agriculture and Rural Working Paper Series, working paper 54.

Hofs, J. L., Hau, B., Marais, D., \& Fok, M. (2006). Boll distribution patterns in Bt and non-Bt cotton cultivars. II. Study on small-scale farming systems in South Africa. Field Crop Research, 98, 210-215. https://doi.org/10.1016/j.fcr.2006.01.007

James, C. (2008). Global status of commercialized biotech/GM crops: 2008 (ISAAA Brief 39). Ithaca, NY: ISAAA.

JORF. (2012). Décret $\mathrm{n}^{\circ} 2012-128$ of the $30^{\text {th }}$ of January 2012 "relatif à l'étiquetage des denrées alimentaires issues de filières qualifies "sans organismes génétiquement modifiés". JORF, 0026, 1770. 
Le Bail, M., \& Valceschini, E. (2004). Efficacité et organisation de la séparation OGM/non OGM. Economie et Société. Série «Systèmes Agroalimentaires», 12(4), 18-29.

Long, T. B., Blok, V., \& Coninx, I. (2016). Barriers to the adoption and diffusion of technological innovations for climate-smart agriculture in Europe: evidence from the Netherlands, France, Switzerland and Italy. Journal of Cleaner Production, 112, 9-21. https://doi.org/10.1016/j.jclepro.2015.06.044

Makkonen, H., Johnston, W. J., \& Javalgi, R. R. G. (2016). A behavioral approach to organizational innovation adoption. Journal of Business Research, 69(7), 2480-2489. https://doi.org/10.1016/j.jbusres.2016.02.017

Ménard, C., \& Klein, P. G. (2004). Organizational issues in the agrifood sector: toward a comparative approach. $\begin{array}{llll}\text { American Journal of Agricultural } & \text { Economics, } & 86(3), & \text { 750-755. }\end{array}$ https://doi.org/10.1111/j.0002-9092.2004.00619.x

Messean, A., Angevin, F., Gómez-Barbero, M., Menrad, K., \& Rodríguez-Cerezo, E. (2006). New case Studies on the co-existence of GM and non-GM crops in European agriculture. IPTS. EU-Joint Research Centre.

Miles, M. N., \& Hubermen, A. M. (1994). Qualitative data analysis, an expended sourcebook. CA: Sage Publications.

Moscardi, E., \& de Janvry, A. (1977). Attitudes towards risk among peasants: An econometric approach. American Journal of Agricultural Economics, 59, 710-716. https://doi.org/10.2307/1239398

Olson, M. (1965). The Logic of Collective Action: Public Goods and the Theory of Groups. Cambridge, MA: Harvard University Press.

République Française. (2008). Registre National des cultures OGM. Retrieved 5 September 2007, from http://www.ogm.gouv.fr/mise_marche/registre_cultures/registre_cultures.htm

Rogers, E. M. (1962). Diffusion of innovations (1st ed.). Glencoe, IL: The Free Press.

Sanvido, O., Widmer, F., Winzler, M., Streit, B., Szerencsits, E., \& Bigler, F. (2008). Definition and feasibility of isolation distances for transgenic maize cultivation. Transgenic Research, 17, 317-335. https://doi.org/10.1007/s11248-007-9103-1

Scipioni, A., Saccarola, G., Arena, F., \& Alberto, S. (2005). Strategies to assure the absence of GMO in food products application process in a confectionery firm. Food Control, 16, 569-578. https://doi.org/10.1016/j.foodcont.2004.06.018

Warren, C. R., Burton, R., Buchanan, O., \& Birnie, R. V. (2016). Limited adoption of short rotation coppice: The role of farmers' socio-cultural identity in influencing practice. Journal of Rural Studies, 45, 175-183. https://doi.org/10.1016/j.jrurstud.2016.03.017

Williamson, O. E. (1981). The Economics of Organization: The Transaction Cost Approach. The American Journal of Sociology, 87(3), 548-577. https://doi.org/10.1086/227496

Wubeneh, N. G., \& Sanders, J. H. (2006). Farm-level adoption of sorghum technologies in Tigray, Ethiopia. Agricultural Systems, 91(1-2), 122-134. https://doi.org/10.1016/j.agsy.2006.02.002

\section{Note}

Note 1. To prevent pollen dissemination and GM/NGM mixture, it is possible to set up isolation distances between plots of land (Byrne and Fromherz, 2003) and also to stagger production over time (Le Bail, and Valceschini, 2004; Scipioni et al., 2005; Messean et al., 2006; Coléno et al, 2009). All these solutions involve new costs: coordination and/or isolation costs. 